\title{
A Simple, Rapid, and Reliable Titrimetric Method for the Determination of Glycerol at Low Concentration
}

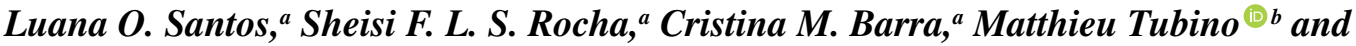 \\ José G. Rocha Junior ${ }^{\circledR} *, a$ \\ ${ }^{a}$ Instituto de Química, Universidade Federal Rural do Rio de Janeiro, 23897-000 Seropédica-RJ, Brazil \\ ${ }^{b}$ Instituto de Química, Universidade Estadual de Campinas, P.O. Box 6154, 13083-970 Campinas-SP, Brazil
}

\begin{abstract}
Glycerol can be determined in several products by various analytical techniques. Titrimetric ones have stood out for their low cost, being recommended as standards. However, reliable, simple, fast, and green methods with low quantification limits are still needed. Titration of glycerol is based on its oxidation by periodate (Malaprade reaction) producing formic acid, formic aldehyde, and iodate. Iodate and periodate are iodometrically titrated, but mutual interference between these ions has produced methods with some drawbacks. Here is proposed to mask periodate with molybdate, to eliminate interference, determining the glycerol content through iodate, employing iodometric titration. Solutions containing from 10 to $1000 \mu \mathrm{g}$ of glycerol were analyzed (error $<3.4 \%$ ). The method was successfully applied for the determination of glycerol in biodiesels from different raw materials. Recoveries were from $92.9 \pm 0.4$ to $111 \pm 3 \%$. Semi-micro extraction was done, providing a fast procedure for determining free glycerol in biodiesel $(<10 \mathrm{~min})$.
\end{abstract}

Keywords: glycerol, periodate, molybdate, Malaprade, biodiesel

\section{Introduction}

Glycerol (1,2,3-propanotriol) is a chemical compound widely employed in cosmetics, pharmaceuticals, detergents, and foods as well as in the manufacture of resins, additives, explosives, papers, and paints. ${ }^{1-3}$ Due to this variety of applications, it is important that new, reliable, fast, and lowcost techniques are being developed to quantify glycerol.

The emollient, moisturizing and conditioning action of glycerol makes this compound used mainly in the formulation of cosmetics such as soaps, shower gels, toothpaste, and cream hair. However, its content in cosmetics must be controlled to avoid allergies and severe skin irritations. ${ }^{4,5}$ In food industries, glycerol provides good sensory implications in several beverages, contributing to viscosity, softness, and flavor. Also, due to its properties it is widely used in adulteration of drinks. ${ }^{4,-8}$ In the beverage industry, the glycerol content is used as an indicator of the quality of fermented alcoholic beverages because it is a co-product of the alcoholic fermentation of sugar. ${ }^{9}$ From a biological point of view, glycerol acts as a key

*e-mail: geraldorocha@ufrrj.br

Editor handled this article: Maria Cristina Canela (Associate) compound in several metabolic pathways, being determined in blood serum and in urine for the diagnosis of metabolic disorders. ${ }^{4,10}$

Glycerol is also a co-product of biodiesel synthesis when this biofuel is produced by the transesterification of triglycerides contained in vegetable oils or animal fats. ${ }^{11,12}$ Therefore, it can be present in biodiesel as free glycerol and as bound glycerol (glycerol portion of the mono-, diand triglyceride molecules). Free and bound glycerol can cause problems in fuel storage tanks, besides clogging and causing deposits in parts of the engine, compromising the combustion process and the performance of the motor. ${ }^{2,13-15}$ To minimize these inconveniences, American Society for Testing and Materials (ASTM), European Committee for Standardization (CEN) and National Agency for Petroleum, Natural Gas and Biofuels (ANP, Brazil) established the limit content of $0.02 \mathrm{~g}$ per $100 \mathrm{~g}$ of free glycerol in biodiesel, through the resolutions ASTM D6751, ${ }^{16}$ EN $14214^{17}$ and 45/2014 (RANP 45/2014), ${ }^{18}$ respectively. As for the total glycerol content, Brazilian and European norms establish a maximum limit of $0.25 \mathrm{~g}$ per $100 \mathrm{~g}$, while in the United States the stipulated limit was $0.24 \mathrm{~g}$ per $100 \mathrm{~g}$.

High performance liquid chromatography (HPLC) and gas chromatography (GC) are techniques widely 
recommended to determine the content of glycerol in various matrices..$^{9,14,19-25}$ Chromatographic techniques present high sensitivity, good reproducibility and low limits of detection and quantification for the determination of the content of glycerol..$^{5}$ However, they have certain limitations, such as the use of expensive and/or hazardous solvents, reagents, analytical standards, materials, and instrumentation. In addition, the use of GC requires derivatization of glycerol, which increases the time required for analysis. . $10,26,27^{2}$

Enzymatic determination of glycerol content using different detection systems is an alternative to chromatographic methods. ${ }^{1,28-33}$ However, despite some advantages of the enzymatic procedure, such as high selectivity and catalytic action, the cost of the enzymes and the loss of their activity are factors to be considered.

Several methods based on the Malaprade reaction (or Malaprade oxidation) have been developed to determine the content of glycerol in different matrices. This reaction involves the cleavage of glycols by the oxidation of the adjacent diols with periodic acid or periodate, in aqueous solution, to give the corresponding carbonyl functional groups. ${ }^{34,35}$ Oxidation of glycerol according to the Malaprade reaction produces formic aldehyde, formic acid, and iodate ion (equation 1). So, glycerol can be indirectly determined through the products of this reaction or by the unreacted periodate ion. , $13,36-47^{-1}$

$$
\mathrm{C}_{3} \mathrm{H}_{8} \mathrm{O}_{3}+2 \mathrm{IO}_{4}^{-} \rightarrow 2 \mathrm{CH}_{2} \mathrm{O}+\mathrm{CH}_{2} \mathrm{O}_{2}+2 \mathrm{IO}_{3}^{-}+\mathrm{H}_{2} \mathrm{O}
$$

The quantification of glycerol from formic aldehyde is carried out based on the formation of 3,5-diacetyl1,4-dihydrolutidine produced in the cyclization reaction of formic aldehyde with acetylacetone (Hantzsch reaction). The 3,5-diacetyl-1,4-dihydrolutidine is then determined by spectrophotometry $(\lambda=410 \mathrm{~nm})$ or by fluorometry $(\lambda=514 \mathrm{~nm}){ }^{37,39,45,46}$ The toxicity and the low stability of the acetylacetone solution and the long time needed to build the analytical curve are factors that hinder the application of these methods, ${ }^{48,49}$ despite using lower cost equipment in comparison to the chromatographic.

Acid-base titration has been used to determine the glycerol content from formic acid produced in the Malaprade oxidation (equation 1). ${ }^{36-38,40,41,43,47}$ The standard method ASTM D7637 $7^{40}$ recommends to titrate the formic acid with a standard solution of $\mathrm{NaOH}$ and bromothymol blue as indicator. However, this procedure is only applicable to aqueous mixtures with a high glycerol content (above $75 \% \mathrm{~m} / \mathrm{m}$ ), which limits its application in several matrices. The AOAC 942.22 standard method ${ }^{36}$ is recommended to analyze glycerol in a cosmetic (vanishing cream), from which it is separated by partition with acidified water/ chloroform. Then, the formic acid produced in the oxidation of glycerol (equation 1) is titrated with a standard aqueous solution of $\mathrm{NaOH}$, using bromocresol purple as indicator. Pisarello et $a l .{ }^{43}$ proposed the determination of free and total glycerol content in biodiesel-diesel blends. After the extraction of glycerol with distilled water the obtained aqueous solution was submitted to a tedious sequence of operations including successive neutralizations. To these boring procedures follows the oxidation with periodate and, then, is necessary to eliminate the excess of this ion using ethylene glycol in order to allow the determination of the formic acid. In general, the methods based on the titration of formic acid require additional steps in the analytical procedure and special care is necessary to avoid the presence of $\mathrm{CO}_{2}$ into solution.

Quantification of glycerol from the remaining periodate or from the iodate produced in the Malaprade reaction (equation 1) has been performed mainly by iodometric titration. These ions are reduced by the iodide, producing triiodide, according to equations 2 and 3, respectively. Then triiodide is titrated using a standard solution of sodium thiosulfate (equation 4) or of arsenious acid (equation 5) and starch as indicator.

$\mathrm{IO}_{4}^{-}+11 \mathrm{I}^{-}+8 \mathrm{H}^{+} \rightarrow 4 \mathrm{I}_{3}^{-}+4 \mathrm{H}_{2} \mathrm{O}$
$\mathrm{IO}_{3}{ }^{-}+8 \mathrm{I}^{-}+6 \mathrm{H}^{+} \rightarrow 3 \mathrm{I}_{3}{ }^{-}+3 \mathrm{H}_{2} \mathrm{O}$
$2 \mathrm{~S}_{2} \mathrm{O}_{3}{ }^{2-}+\mathrm{I}_{3}^{-} \rightarrow 3 \mathrm{I}^{-}+\mathrm{S}_{4} \mathrm{O}_{6}{ }^{2-}$
$\mathrm{H}_{3} \mathrm{AsO}_{3}+2 \mathrm{HO}^{-}+\mathrm{I}_{3}^{-} \rightarrow 3 \mathrm{I}^{-}+\mathrm{H}_{3} \mathrm{AsO}_{4}+\mathrm{H}_{2} \mathrm{O}$

For the iodometric quantification of glycerol in biodiesel, oils, and fats through the ABNT NBR $15771^{50}$ and AOCS Ca $14-56^{51}$ standard methods, the reactions of iodide with the remaining periodate (equation 2) and with the iodate generated in the Malaprade reaction are performed simultaneously (equation 3 ). The glycerol present in the sample is extracted with an acetic acid aqueous solution or with water. It is then determined by the difference between the volume of the titrant used in the titration of the sample minus that of the blank (solvent). However, the high excess of periodate used in the Malaprade reaction, and the low quantity of iodate produced (due to low glycerol content) can cause a situation in which the difference between the volumes of titrant becomes very small, fact which magnifies the relative titration error. To increase this difference, the ABNT NBR 15771 standard method $^{50}$ recommends the use of a large-scale sample. If this is not enough, re-analyses should be performed using different proportions of reagents, procedure which can make the determination very tedious. Therefore, the simultaneous reaction of periodate (equation 2 ) and iodate 
(equation 3) with iodide is not advisable and the analysis should preferably be carried out under conditions that inhibit the reaction of one of these ions.

For the determination of glycerol content in vanishing cream, the AOAC $942.22^{36}$ recommends the iodometric titration carried out in the presence of sodium bicarbonate $(\mathrm{pH} 8)$, condition in which only the periodate reacts with iodide (equation 2). The glycerol is extracted with $\mathrm{H}_{2} \mathrm{SO}_{4}$ aqueous solution and then quantified by the difference between the amount of periodate added to the Malaprade reaction (obtained by titrating a blank) and the periodate remaining at the end of this reaction (determined by the titration of the sample). However, the method employs toxic substances, such as $\mathrm{H}_{3} \mathrm{AsO}_{3}$ and chloroform.

Although the low cost, all titrimetric methods above reported require a long time for analysis ( $>60 \mathrm{~min}$ ), because the Malaprade reaction is kinetically disadvantaged under the employed conditions. This problem is minimized if a high excess of periodate is used, but this leads to a substantial increase in titrant volume for the blank and for the sample, decreasing the sensitivity of the method. Alternatively, the excess of periodate is removed with other glycols so that the titrant volume for the blank is decreased and consequently the sensitivity is increased. However, with this procedure the analysis time becomes higher. Ideally, the Malaprade reaction should take place quickly, and the unreacted periodate should be promptly eliminated so that only the reaction of the iodate with the iodide occurs in the titration. In this case, the volume of titrant becomes directly proportional to the amount of glycerol in the sample.

Belcher and Townshend ${ }^{52}$ proposed an iodometric titration for the determination of periodate and iodate in aqueous solutions containing a mixture of these ions. Sodium molybdate was used to mask the periodate (equation 6) and then iodide was added to react only with the iodate, according to equation 3 . The produced triiodide was titrated with a standard sodium thiosulfate solution (equation 4). A second titration was carried out without the masking agent, and the periodate was determined by the difference between the volumes of the titrant spent in the two titrations.

$$
6 \mathrm{MoO}_{4}{ }^{2-}+\mathrm{IO}_{4}^{-}+8 \mathrm{H}^{+} \rightarrow\left[\mathrm{I}^{-}\left(\mathrm{MoO}_{4}\right)_{6}\right]^{5-}+4 \mathrm{H}_{2} \mathrm{O}
$$

Nakashima et al. ${ }^{53}$ by masking periodate with molybdate, determined periodate and iodate in water using capillary electrophoresis. According to these authors, the masking reaction (equation 6) is rapid and selective in a $\mathrm{pH}$ range of 3.0 to 4.5. In addition, the formed complex $\left(\left[\mathrm{I}\left(\mathrm{MoO}_{4}\right)_{6}\right]^{5-}\right)$ was stable over a week in this condition. Ensafi and Chamjangali ${ }^{54}$ performed the sequential flow injection determination of iodate and periodate with spectrophotometric detection in water samples, using molybdate to mask periodate.

The present work proposes a reliable analytical procedure for the rapid determination of glycerol at low concentrations in aqueous medium using the Malaprade reaction. The method is based on the: (i) oxidation of glycerol with periodate (equation 1); (ii) masking of excess periodate with molybdate (equation 6); (iii) iodometric titration of iodate with thiosulfate (equation 4). As far as we know, for the determination of glycerol content, molybdate ion has not been used yet as masking agent for the unreacted periodate in the Malaprade reaction. The here proposed method was applied to determine the content of free glycerol in biodiesel produced from different raw materials, using semi-micro extraction procedure in order to have low reagents consumption and shorter analysis time.

\section{Experimental}

\section{Apparatus}

Volumetric flasks, pipettes and burettes class A were used. The preparations of standard and reference solutions were performed with 250 and $100 \mathrm{~mL}$ volumetric flasks, $10 \mathrm{~mL}$ pipette, $100-1000 \mu \mathrm{L}$ micropipette $( \pm 0.005 \mu \mathrm{L})$ and $1000-5000 \mu \mathrm{L}$ micropipette $( \pm 0.01 \mu \mathrm{L})$. Titrations were performed with 25,10 , and $5 \mathrm{~mL}$ burettes.

\section{Reagents and materials}

All reagents used were of analytical grade. Deionized water was employed to prepare the solutions. Sodium periodate solutions of 50 and of $5 \mathrm{mmol} \mathrm{L}^{-1}$ were prepared dissolving, respectively, 2.68 and $0.268 \mathrm{~g}$ of $\mathrm{NaIO}_{4}$ (Vetec, Duque de Caxias, Brazil) in $250 \mathrm{~mL}$ of water. These solutions were stored in closed amber flasks lined with aluminum foil. The aliquots taken from the solutions used for the analyses were pipetted directly from the flasks, which were closed immediately afterwards. A $0.2 \mathrm{~mol} \mathrm{~L}^{-1}$ sodium molybdate solution was prepared dissolving $12.1 \mathrm{~g}$ of $\mathrm{Na}_{2} \mathrm{MoO}_{4} \cdot 2 \mathrm{H}_{2} \mathrm{O}$ (Vetec, Duque de Caxias, Brazil) in $250 \mathrm{~mL}$ of water. The solution was kept protected from light. A $2.0 \%$ potassium iodide $(\mathrm{m} / \mathrm{v})$ was prepared dissolving $5.0 \mathrm{~g}$ of KI (Êxodo Científica, Sumaré, Brazil) in $250 \mathrm{~mL}$ of water. A $3.0 \mathrm{~mol} \mathrm{~L}^{-1}$ sulfuric acid solution was prepared by carefully diluting $33 \mathrm{~mL}$ of concentrated $\mathrm{H}_{2} \mathrm{SO}_{4}$ (Vetec, Duque de Caxias, Brazil) in $200 \mathrm{~mL}$ of water. A $2.8 \mathrm{~mol} \mathrm{~L}^{-1}$ acetic acid solution at $\mathrm{pH} 3$ was prepared by diluting $85 \mathrm{~mL}$ of glacial acetic acid (Vetec, Duque de Caxias, Brazil) with $415 \mathrm{~mL}$ of water and dissolving 
$0.666 \mathrm{~g}$ of sodium hydroxide (Vetec, Duque de Caxias, Brazil) in order to adjust the $\mathrm{pH}$. $1 \%$ starch $(\mathrm{m} / \mathrm{v})$ solution was prepared by mixing $1.0 \mathrm{~g}$ of starch (Cinética Reagentes e Soluções, Jandira, Brazil) in $50 \mathrm{~mL}$ of water at room temperature. Afterwards, $50 \mathrm{~mL}$ of boiling water were added under vigorous agitation. The produced solution was boiled until it was transparent and then left to cool at room temperature. Glycerol (99.5\%, Sigma-Aldrich, Duque de Caxias, Brazil), potassium iodate (99.4-100.4\%, Vetec, Duque de Caxias, Brazil) and sodium thiosulfate $(\geq 99.5 \%$, Impex, São Paulo, Brazil) were used to prepare reference and standard solutions.

Biodiesels from soybean oil, palm kernel oil, macauba kernel oil, and used frying oil were synthesized and purified according to the methodology described by Rocha Jr. et al..$^{55}$

\section{Preparation of reference and standard solutions}

Glycerol reference stock solution (10000 $\mathrm{mg} \mathrm{L}^{-1}$ ) was prepared by weighing approximately $1000 \mathrm{mg}$ (accuracy $\pm 0.1 \mathrm{mg}$ ) of glycerol into a $100 \mathrm{~mL}$ volumetric flask, adding water to complete the volume. Glycerol reference solutions (GRS) of $10-1000 \mathrm{mg} \mathrm{L}^{-1}$ were produced by pipetting aliquots of stock solution to a $100 \mathrm{~mL}$ volumetric flask, adding water up to the mark. Potassium iodate standard solutions of approximately 4 and $1.3 \mathrm{mmol} \mathrm{L}^{-1}$ were prepared by dissolving with water into beakers, respectively, 210 and $70 \mathrm{mg}$ (accuracy $\pm 0.1 \mathrm{mg}$ ) of $\mathrm{KIO}_{3}$. The solutions were quantitatively transferred to $250 \mathrm{~mL}$ volumetric flasks which were adequately filled with water up to the mark. Standard solutions of 20 and $5 \mathrm{mmol} \mathrm{L}^{-1}$ of sodium thiosulfate were prepared by adequately dissolving 1.2 and $0.3 \mathrm{~g}$, respectively, of $\mathrm{Na}_{2} \mathrm{~S}_{2} \mathrm{O}_{3}$ with $250 \mathrm{~mL}$ of water. These sodium thiosulfate solutions were standardized titrating against potassium iodate solutions.

\section{Standardization of sodium thiosulfate solutions}

For the standardization of the $20 \mathrm{mmol} \mathrm{L}^{-1} \mathrm{Na}_{2} \mathrm{~S}_{2} \mathrm{O}_{3}$ solution, a $10 \mathrm{~mL}$ aliquot of the aqueous standard solution of $4 \mathrm{mmol} \mathrm{L}^{-1} \mathrm{KIO}_{3}$ was pipetted into a $250 \mathrm{~mL}$ conical flask. Then, $1.0 \mathrm{~mL}$ of $3.0 \mathrm{~mol} \mathrm{~L}^{-1} \mathrm{H}_{2} \mathrm{SO}_{4}$ and $2.5 \mathrm{~mL}$ of $2.0 \% \mathrm{KI}(\mathrm{m} / \mathrm{v})$ aqueous solutions were added. Using a $25 \mathrm{~mL}$ burette, the mixture was titrated with the $20 \mathrm{mmol} \mathrm{L}{ }^{-1} \mathrm{Na}_{2} \mathrm{~S}_{2} \mathrm{O}_{3}$ solution until a light-yellow color appeared, when the titration was interrupted. Then, $1.0 \mathrm{~mL}$ of $1 \%$ starch indicator $(\mathrm{m} / \mathrm{v})$ solution was added, producing dark blue color solution. Finally, the titration was continued until the blue color disappearance. The titration was carried out in triplicate.
The standardization of $5 \mathrm{mmol} \mathrm{L} \mathrm{Na}_{2} \mathrm{~S}_{2} \mathrm{O}_{3}$ solution was similarly performed, however, the standard solution of $4 \mathrm{mmol} \mathrm{L}^{-1} \mathrm{KIO}_{3}$ was replaced by another of $1.3 \mathrm{mmol} \mathrm{L}^{-1} \mathrm{KIO}_{3}$.

Proposed method for the determination of the glycerol content

The proposed method was initially employed to determine the glycerol content in the GRS. For the analysis of the GRS with concentrations in the range from $10-100 \mathrm{mg} \mathrm{L}^{-1}, 1000 \mu \mathrm{L}$ of GRS and $1000 \mu \mathrm{L}$ of $5 \mathrm{mmol} \mathrm{L}^{-1} \mathrm{NaIO}_{4}$ solutions were transferred to a $10 \mathrm{~mL}$ test tube having a screw cap. A $100-1000 \mu \mathrm{L}$ micropipette was used for the transfers. The test tube was closed, vigorously shaken for $3 \mathrm{~min}$ and the content was transferred to a $250 \mathrm{~mL}$ conical flask. The inner walls of the test tube were washed with three portions of the $2.8 \mathrm{~mol} \mathrm{~L}^{-1}$ acetic acid solution at $\mathrm{pH}$ 3.0. Each washing solution (totalizing $10 \mathrm{~mL}$ ) was transferred to a $250 \mathrm{~mL}$ conical flask containing the glycerol/ $/ \mathrm{NaIO}_{4}$ mixture. Then, $3.0 \mathrm{~mL}$ of $0.20 \mathrm{~mol} \mathrm{~L}^{-1} \mathrm{Na}_{2} \mathrm{MoO}_{4} \cdot 2 \mathrm{H}_{2} \mathrm{O}$ solution was added and the mixture was vigorously stirred. Finally, $2.0 \mathrm{~mL}$ of $2.0 \% \mathrm{KI}(\mathrm{m} / \mathrm{v})$ was added, and the resulting solution was titrated with $20 \mathrm{mmol} \mathrm{L} \mathrm{ma}_{2} \mathrm{~S}_{2} \mathrm{O}_{3}$ solution using a $5 \mathrm{~mL}$ burette, until observing a light-yellow color, when the titration was interrupted for the addition of $1.0 \mathrm{~mL}$ of $1 \%(\mathrm{~m} / \mathrm{v})$ starch indicator solution. Then, it was resumed until the disappearance of the blue color for at least $30 \mathrm{~s}$.

Analysis of the blank was performed by replacing the GRS by the solvent (deionized water) and putting the starch indicator solution immediately after adding $2.0 \% \mathrm{KI}(\mathrm{m} / \mathrm{v})$. All titrations were carried out in quadruplicates.

Analyses of the 100 to $1000 \mathrm{mg} \mathrm{L}^{-1}$ concentrations of GRS were performed by a similar procedure, but in these cases the less diluted $\mathrm{NaIO}_{4}$ solution $\left(50 \mathrm{mmol} \mathrm{L}{ }^{-1}\right)$ and a $10 \mathrm{~mL}$ burette were used.

The glycerol content in the GRS was calculated according to equation 7 .

$\mathrm{GL}_{\mathrm{GRS}}=\frac{\mathrm{C}_{\mathrm{Na}_{2} \mathrm{~S}_{2} \mathrm{O}_{3}} \times\left(\mathrm{V}_{\mathrm{Na}_{2} \mathrm{~S}_{2} \mathrm{O}_{3}}-\mathrm{V}_{\mathrm{b}}\right) \times 92.09}{12}$

where $\mathrm{GL}_{\mathrm{GRS}}$ is the glycerol content in the GRS, in $\mathrm{mg} \mathrm{L}^{-1}$; $\mathrm{C}_{\mathrm{Na}_{2} \mathrm{~S}_{2} \mathrm{O}_{3}}$ is the concentration of the standard $\mathrm{Na}_{2} \mathrm{~S}_{2} \mathrm{O}_{3}$ solution, in mmol L-1; $\mathrm{V}_{\mathrm{Na}_{2} \mathrm{~S}_{2} \mathrm{O}_{3}}$ and $\mathrm{V}_{\mathrm{b}}$ are the volumes, in $\mathrm{mL}$, of the $\mathrm{Na}_{2} \mathrm{~S}_{2} \mathrm{O}_{3}$ solution spent for the titration of the glycerol solution and of the blank, respectively; 92.09 is the molar mass of glycerol, in $\mathrm{g} \mathrm{mol}^{-1}$, and 12 is the stoichiometric factor. 


\section{Analysis of real samples and recovery}

The proposed method was employed to determinate the free glycerol content in biodiesels from soybean oil, palm kernel oil, macauba kernel oil and used frying oil.

To perform the analysis, $400 \mu \mathrm{L}$ of biodiesel were transferred to a $10 \mathrm{~mL}$ tared test tube with screw cap. The sample mass was determined using an analytical balance $( \pm 0.0001 \mathrm{~g})$. Free glycerol was extracted by adding $1600 \mu \mathrm{L}$ of deionized water, $1600 \mu \mathrm{L}$ of $n$-heptane, and vigorously shaking for $1 \mathrm{~min}$. The mixture was then centrifuged at $2000 \mathrm{rpm}$ for $1 \mathrm{~min}$ to separate the aqueous phase from the organic one. In sequence, an aliquot of $1000 \mu \mathrm{L}$ of the aqueous phase was pipetted into a $10 \mathrm{~mL}$ test tube with screw cap and analyzed using the same procedure above described for the analysis of $1000 \mu \mathrm{L}$ of GRS (10-100 $\left.\mathrm{mg} \mathrm{L}^{-1}\right)$. Determinations were performed in quintuplicates.

The free glycerol content in the biodiesel was calculated according to equation 8 .

$\mathrm{GL}_{\mathrm{BD}}=\frac{\mathrm{V}_{\mathrm{E}} \times \mathrm{C}_{\mathrm{Na}_{2} \mathrm{~S}_{2} \mathrm{O}_{3}} \times\left(\mathrm{V}_{\mathrm{Na}_{2} \mathrm{~S}_{2} \mathrm{O}_{3}}-\mathrm{V}_{\mathrm{b}}\right) \times 92.09}{\mathrm{~V}_{\mathrm{A}} \times \mathrm{m}_{\mathrm{bio}} \times 12} \times 0.1$

where $\mathrm{GL}_{\mathrm{BD}}$ is the free glycerol content in the biodiesel, in $\mathrm{g}$ per $100 \mathrm{~g} ; \mathrm{m}_{\text {bio }}$ is the mass of the analyzed biodiesel, in $\mathrm{mg} ; \mathrm{V}_{\mathrm{E}}$ and $\mathrm{V}_{\mathrm{A}}$ are the volumes, in $\mathrm{mL}$, of the aqueous extract $(1600 \mu \mathrm{L})$ and of the titrated solution $(1000 \mu \mathrm{L})$, respectively; and 0.1 is the conversion factor used to express the concentration of $\mathrm{GL}_{\mathrm{BD}}$ in $\mathrm{g}$ per $100 \mathrm{~g}$.

The accuracy of the proposed method was evaluated performing recovery tests. Biodiesels samples were fortified with $100 \mu \mathrm{L}$ of glycerol standards at three different concentrations $\left(250,500\right.$ and $\left.1000 \mathrm{mg} \mathrm{L}^{-1}\right)$ which cause increases of approximately $0.03,0.06$, and $0.13 \mathrm{~g}$ per $100 \mathrm{~g}$ in the free glycerol contents. The extractions and determinations of the free glycerol contents of the fortified samples were carried out according to the procedure adopted in the analysis of the biodiesels samples. The determinations were performed in quintuplicates.

\section{Monitoring the solutions of $\mathrm{NaIO}_{4}$}

Periodate ions react with water producing iodate ions which react with sodium thiosulfate causing a systematic error in the analysis, unless the volume of titrant spent on the blank titration is taken into account. ${ }^{56,57}$ Even though from a thermodynamic point of view they are unstable, periodate solutions have been reported ${ }^{56}$ to be kinetically stable, regardless of the $\mathrm{pH}$ value, as they oxidize water very slowly.

The 50 and $5 \mathrm{mmol} \mathrm{L}^{-1}$ sodium periodate solutions were monitored to investigate whether they are stable enough to dispense blank titration. For such, after the preparation of the $\mathrm{NaIO}_{4}$ solutions, the blank analysis was performed over time: in each case the number of drops of sodium thiosulfate solution necessary to change the color of the indicator was counted. The titrations were performed with sodium thiosulfate solutions of concentrations of $20 \mathrm{mmol} \mathrm{L}^{-1}$ (with $10 \mathrm{~mL}$ burette) and of $5 \mathrm{mmol} \mathrm{L}^{-1}$ (with $5 \mathrm{~mL}$ burette) versus, respectively, 50 and with $5 \mathrm{mmol} \mathrm{L}^{-1}$ solutions of sodium periodate.

In order to investigate the effect of storage conditions, two groups of periodate solutions, used in this study, were stored in different conditions: $(i)$ in closed flasks protected from light and from the environment; (ii) in open flasks unprotected from light and exposed to the environment.

\section{Results and Discussion}

Monitoring the solutions of $\mathrm{NaIO}_{4}$

The monitoring of the sodium periodate solutions over time revealed that when exposed to the environment (atmosphere; light), until nine hours after their preparations, the iodate concentration does not decrease enough to influence the determination of glycerol (Figure 1). For both 50 and $5 \mathrm{mmol} \mathrm{L}{ }^{-1}$ solutions, either stored in open flasks or in closed flasks, only one drop of titrant was enough to turn the blue color of the solution (iodinestarch complex) to colorless (one drop corresponds to $0.04 \mathrm{~mL}$ for the $5 \mathrm{~mL}$ burette and to $0.07 \mathrm{~mL}$ for the $10 \mathrm{~mL}$ burette). Therefore, in such conditions, the reduction of the periodate ion in aqueous solution, due to light and other environmental conditions, producing iodate ion, is very small and it does not promote appreciable error in analysis.

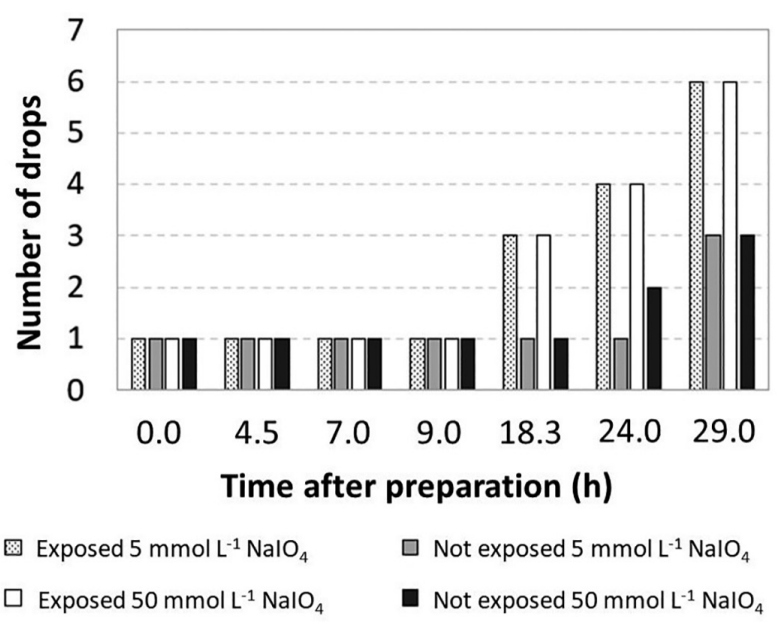

Figure 1. Number of drops of 20 and $5 \mathrm{mmol} \mathrm{L}^{-1} \mathrm{Na}_{2} \mathrm{~S}_{2} \mathrm{O}_{3}$ solutions for the blank titration with 50 and $5 \mathrm{mmol} \mathrm{L}^{-1} \mathrm{NaIO}_{4}$ solutions, respectively, both exposed and not exposed to environment (atmosphere; light). 
Particularly, the periodate solutions stored in closed flasks and protected from light were not affected up to about $18.3 \mathrm{~h}$ after preparation. However, solutions stored in open flasks unprotected from light and environment, consumed from three to six drops of titrant when analyzed from about $18.3 \mathrm{~h}$ of storage or more (Figure 1).

If only one drop of titrant is spent in the titration of the blank it was disregarded in the calculations, because the volume of one drop was within the uncertainty of the volume of the added titrant.

The use of fresh solutions of $\mathrm{NaIO}_{4}$ dispenses the blank analysis and the equations 7 and 8 can be changed to equations 9 and 10 , respectively.

$$
\begin{aligned}
\mathrm{GL}_{\mathrm{GRS}} & =\frac{\mathrm{C}_{\mathrm{Na}_{2} \mathrm{~S}_{2} \mathrm{O}_{3}} \times \mathrm{V}_{\mathrm{Na}_{2} \mathrm{~S}_{2} \mathrm{O}_{3}} \times 92.09}{12} \\
\mathrm{GL}_{\mathrm{BD}} & =\frac{\mathrm{V}_{\mathrm{E}} \times \mathrm{C}_{\mathrm{Na}_{2} \mathrm{~S}_{2} \mathrm{O}_{3}} \times \mathrm{V}_{\mathrm{Na}_{2} \mathrm{~S}_{2} \mathrm{O}_{3}} \times 92.09}{\mathrm{~V}_{\mathrm{A}} \times \mathrm{m}_{\text {bio }} \times 12} \times 0.1
\end{aligned}
$$

\section{Glycerol content in the reference solutions}

The glycerol contents in GRS were determined by the proposed method with good accuracy (errors $\leq 13.41 \%$ ) and precision (coefficient of variation $\leq 8.0 \%$ ) (Table 1). For the three highest glycerol concentrations in each series (100-1000 $\mathrm{mg} \mathrm{L}^{-1}$ and $10-100 \mathrm{mg} \mathrm{L}^{-1}$ ), the coefficients of variation were $\leq 1.7 \%$ due to the increase of the titrant volume. The Student's $t$-test revealed that, except in the GRS of 78.2 and $58.6 \mathrm{mg} \mathrm{L}^{-1}$ where the calculated $t$ values (4.14 and 3.29) were a little higher than the critical value (3.18), all average glycerol levels determined experimentally did not differ statistically from the glycerol content of the GRS, at the significance level $(\alpha)$ of 0.05 (degree of freedom $=3$ ). Notwithstanding, the relative errors in the GRS of 78.2 and $58.6 \mathrm{mg} \mathrm{L}^{-1}$ solutions were $\leq 13.01 \%$.

All titrimetric methods are subject to a systematic error caused by the indicator. As the volumes of titrants spent in the $10-100 \mathrm{mg} \mathrm{L}^{-1}$ GRS are very low, this systematic error will be greater and, consequently, its reflection in the Student's $t$-test can lead to an augmented $t$-value. Nevertheless, in the present case, this effect was only observed in the analysis of 78.2 and $58.6 \mathrm{mg} \mathrm{L}^{-1}$ GRS, where the low values of the standard deviations imposed a narrowing of the confidence intervals.

The time required to perform one determination of the glycerol content in an aqueous solution, through the proposed method, is about $5 \mathrm{~min}$. This time is quite less than that usually required by the current titrimetric procedures to determine this analyte in aqueous matrices. In the usual current titration methods only the step of glycerol oxidation with periodate (equation 1) requires from 10 to $90 \mathrm{~min}$ while the procedure here proposed requires only $3 \mathrm{~min}$ (Table 2). According to the work published by Hartman, ${ }^{60}$ 3 min would be enough time for the complete oxidation of glycerol by periodate.

Some current titration methods also employ small time intervals for the Malaprade reaction but in these procedures additional steps are required ( $\mathrm{pH}$ adjustments, elimination of the unreacted periodate, and elimination of $\mathrm{CO}_{2}$ ) causing increase in the determination time. ${ }^{60,61} \mathrm{Also}$, some methods use harmful reagents and solvents which present risk to human health and to the environment (sodium arsenite

Table 1. Nominal and experimental glycerol contents in GRS (from 100 to $1000 \mathrm{mg} \mathrm{L}^{-1}$ and 10 to $100 \mathrm{mg} \mathrm{L}^{-1}$ ), mean volume of the $\mathrm{Na}_{2} \mathrm{~S}_{2} \mathrm{O}_{3}$ solution spent

\begin{tabular}{|c|c|c|c|c|c|c|}
\hline $\begin{array}{l}\text { Concentration } \\
\text { range / }\left(\mathrm{mg} \mathrm{L}^{-1}\right)\end{array}$ & $\begin{array}{c}\text { Nominal } \\
\text { content / }\left(\mathrm{mg} \mathrm{L}^{-1}\right)\end{array}$ & $\begin{array}{l}\text { Volume of } \\
\text { titrant / mL }\end{array}$ & $\begin{array}{c}\text { Experimental } \\
\text { content / }\left(\mathrm{mg} \mathrm{L}^{-1}\right)\end{array}$ & $\begin{array}{l}\text { Coefficient of } \\
\text { variation / \% }\end{array}$ & Error / \% & $t$ value $^{\mathrm{a}}$ \\
\hline \multirow{6}{*}{$100-1000^{\mathrm{b}}$} & 997 & $6.44 \pm 0.05$ & $995 \pm 6$ & 0.6 & -0.2 & 0.23 \\
\hline & 798 & $5.26 \pm 0.05$ & $785 \pm 5$ & 0.6 & -1.6 & 1.26 \\
\hline & 598 & $3.77 \pm 0.04$ & $595 \pm 10$ & 1.7 & -0.50 & 0.15 \\
\hline & 391 & $2.58 \pm 0.07$ & $385 \pm 10$ & 2.8 & -1.5 & 0.27 \\
\hline & 195 & $1.29 \pm 0.05$ & $193 \pm 7$ & 3.6 & -1.0 & 0.17 \\
\hline & 99.7 & $0.648^{c} \pm 0.010$ & $96.3 \pm 1.4$ & 1.5 & -3.4 & 1.2 \\
\hline \multirow{6}{*}{$10-100^{\mathrm{d}}$} & 97.7 & $2.388 \pm 0.010$ & $97.93 \pm 0.10$ & 0.1 & 0.24 & 0.23 \\
\hline & 78.2 & $1.946 \pm 0.005$ & $79.8 \pm 0.2$ & 0.3 & 2.1 & 4.15 \\
\hline & 58.6 & $1.471 \pm 0.006$ & $60.3 \pm 0.3$ & 0.5 & 2.9 & 3.29 \\
\hline & 40.2 & $1.04^{c} \pm 0.04$ & $40.0 \pm 1.6$ & 4.0 & -0.5 & 0.05 \\
\hline & 20.1 & $0.522^{\mathrm{c}} \pm 0.010$ & $20.0 \pm 0.4$ & 2.0 & -0.5 & 0.06 \\
\hline & 10.0 & $0.27^{\mathrm{c}} \pm 0.02$ & $10.3 \pm 0.8$ & 8.0 & 3.0 & 0.13 \\
\hline
\end{tabular}
in each titration, coefficient of variation, and relative error of each analysis

${ }^{\mathrm{a}} t$ critical value $=3.18$ (degree of freedom $=3 ; \alpha=0.05$ ); ${ }^{\mathrm{b}} 20 \mathrm{mmol} \mathrm{L}{ }^{-1} \mathrm{Na}_{2} \mathrm{~S}_{2} \mathrm{O}_{3}$ solution and $10 \mathrm{~mL}$ burette; cthe blank was discounted, according to equation 7; 5 mmol L-1 $\mathrm{Na}_{2} \mathrm{~S}_{2} \mathrm{O}_{3}$ solution and $5 \mathrm{~mL}$ burette. 
Table 2. Known titrimetric methods for the determination of the content of glycerol in various matrices and some of their characteristics, in comparison with the proposed iodometric method

\begin{tabular}{|c|c|c|c|c|c|c|c|c|c|c|}
\hline Principle & Sample & $\begin{array}{l}\text { Mass of } \\
\text { glycerol }\end{array}$ & $\begin{array}{c}\text { Oxidant } \\
\text { agent/mass }\end{array}$ & $\begin{array}{c}\text { time for } \\
\text { Malaprade } \\
\text { reaction / min }\end{array}$ & $\begin{array}{l}\text { Agent for } \\
\text { periodate } \\
\text { elimination }\end{array}$ & $\begin{array}{c}\text { time for } \\
\text { periodate } \\
\text { elimination / } \\
\text { min }\end{array}$ & Blank & Titrant & $\begin{array}{l}\text { Previous } \\
\text { steps }{ }^{\mathrm{a}} \\
\text { estimated } \\
\text { time }^{\mathrm{b}}\end{array}$ & Reference \\
\hline \multirow{5}{*}{ Iodometric } & biodiesel & $4 \mathrm{mg}$ & $\begin{array}{l}\mathrm{H}_{5} \mathrm{IO}_{6} / \\
67.5 \mathrm{mg}\end{array}$ & $30-90$ & none & - & yes & $\mathrm{Na}_{2} \mathrm{~S}_{2} \mathrm{O}_{3}$ & none & 50 \\
\hline & $\begin{array}{l}\text { vanishing } \\
\text { cream }\end{array}$ & $30-40 \mathrm{mg}$ & $\begin{array}{l}\mathrm{KIO}_{4} / \\
230 \mathrm{mg}\end{array}$ & 60 & none & - & yes & $\mathrm{H}_{3} \mathrm{AsO}_{3}$ & none & 36 \\
\hline & fats and oils & $600 \mu \mathrm{g}$ & $\begin{array}{l}\mathrm{NaIO}_{4} / \\
275 \mathrm{mg}\end{array}$ & 10 & $\mathrm{NaHCO}_{3}$ & immediately & yes & $\mathrm{NaAsO}_{2}$ & none & $58^{\mathrm{c}}$ \\
\hline & fats and oils & $15 \mu \mathrm{g}$ & $\begin{array}{l}\mathrm{HIO}_{4} / \text { not } \\
\text { reported }\end{array}$ & 30 & none & - & yes & $\mathrm{Na}_{2} \mathrm{~S}_{2} \mathrm{O}_{3}$ & none & $59^{\mathrm{d}}$ \\
\hline & water & $30 \mathrm{mg}$ & $\begin{array}{c}\mathrm{KIO}_{4} / \\
350 \mathrm{mg}\end{array}$ & 5 & $\mathrm{KAsO}_{2}{ }^{\mathrm{e}}$ & 10 & yes & chloramine- $\mathrm{T}$ & none & 60 \\
\hline \multirow{2}{*}{ Potentiometric } & fats and oils & 43-208 mg & $\mathrm{NaIO}_{4} / 2.5 \mathrm{~g}$ & 1 & $\begin{array}{l}\text { ethylene } \\
\text { glycol }\end{array}$ & 5 & no & $\mathrm{NaOH}$ & $\begin{array}{c}\mathrm{pH} \\
\text { adjustments/ } \\
3 \mathrm{~min}\end{array}$ & 61 \\
\hline & $\begin{array}{l}\text { commercial } \\
\text { glycerin }\end{array}$ & $150 \mathrm{mg}$ & $\mathrm{H}_{5} \mathrm{IO}_{6} / 1 \mathrm{~g}$ & 60 & none & - & yes & $\mathrm{NaOH}$ & $\begin{array}{c}\mathrm{pH} \\
\text { adjustments/ } \\
3 \mathrm{~min}\end{array}$ & 62 \\
\hline \multirow{8}{*}{ Alkalimetric } & water & $400 \mathrm{mg}$ & $\mathrm{NaIO}_{4} / 3 \mathrm{~g}$ & 30 & $\begin{array}{l}\text { ethylene } \\
\text { glycol }\end{array}$ & 20 & yes & $\mathrm{NaOH}$ & $\begin{array}{l}\text { evaluation } \\
\text { of } \mathrm{NaIO}_{4} \\
\text { solution/ } \\
38 \mathrm{~min}\end{array}$ & 40 \\
\hline & $\begin{array}{l}\text { vanishing } \\
\text { cream }\end{array}$ & $30-40 \mathrm{mg}$ & $\begin{array}{l}\mathrm{KIO}_{4} / \\
230 \mathrm{mg}\end{array}$ & 60 & $\begin{array}{l}\text { propylene } \\
\text { glycol }\end{array}$ & 10 & no & $\mathrm{NaOH}$ & none & 36 \\
\hline & $\begin{array}{c}\text { resin } \\
\text { solutions }\end{array}$ & $19-26 \mathrm{mg}$ & $\begin{array}{l}\mathrm{HIO}_{4} / \\
550 \mathrm{mg}\end{array}$ & $50-70$ & none & - & yes & $\mathrm{NaOH}$ & $\begin{array}{c}\mathrm{pH} \\
\text { adjustments/ } \\
3 \text { min }\end{array}$ & 63 \\
\hline & glycerol & $100-120 \mathrm{mg}$ & $\mathrm{KIO}_{4} / 1.4 \mathrm{~g}$ & 5 & $\begin{array}{l}\text { propylene } \\
\text { glycol }\end{array}$ & few minutes ${ }^{\mathrm{f}}$ & yes & $\mathrm{NaOH}$ & $\begin{array}{c}\mathrm{pH} \\
\text { adjustments/ } \\
3 \mathrm{~min}\end{array}$ & 58 \\
\hline & biodiesel & $5-20 \mathrm{mg}$ & $\begin{array}{l}\mathrm{NaIO}_{4} / \\
900 \mathrm{mg}\end{array}$ & 30 & $\begin{array}{l}\text { ethylene } \\
\text { glycol }\end{array}$ & 20 & no & $\mathrm{NaOH}$ & $\begin{array}{c}\mathrm{pH} \\
\text { adjustments; } \\
\text { boiling for } \\
\mathrm{CO}_{2} \text { removal; } \\
\text { cooling/ } \\
15 \mathrm{~min}\end{array}$ & 38 \\
\hline & $\begin{array}{l}\text { biodiesel/ } \\
\text { diesel blends }\end{array}$ & $0.25-5 \mathrm{mg}$ & $\begin{array}{l}\mathrm{NaIO}_{4} / \\
900 \mathrm{mg}\end{array}$ & 30 & $\begin{array}{l}\text { ethylene } \\
\text { glycol }\end{array}$ & 20 & yes & $\mathrm{NaOH}$ & $\begin{array}{c}\mathrm{pH} \\
\text { adjustments; } \\
\text { boiling for } \\
\mathrm{CO}_{2} \text { removal; } \\
\text { cooling/ } \\
15 \mathrm{~min}\end{array}$ & 43 \\
\hline & $\begin{array}{l}\text { soaps and } \\
\text { glycerin }\end{array}$ & $150 \mathrm{mg}$ & $\begin{array}{l}\mathrm{NaIO}_{4} / \\
900 \mathrm{mg}\end{array}$ & 30 & $\begin{array}{l}\text { ethylene } \\
\text { glycol }\end{array}$ & 20 & sometimes & $\mathrm{NaOH}$ & $\begin{array}{c}\mathrm{pH} \\
\text { adjustments; } \\
\text { boiling for } \\
\mathrm{CO}_{2} \text { removal; } \\
\text { cooling/ } \\
15 \mathrm{~min}\end{array}$ & 64 \\
\hline & $\begin{array}{l}\text { fermented } \\
\text { glycerol } \\
\text { broth }\end{array}$ & $150-250 \mathrm{mg}$ & $\begin{array}{l}\mathrm{NaIO}_{4} / \mathrm{not} \\
\text { reported }\end{array}$ & 30 & $\begin{array}{l}\text { ethylene } \\
\text { glycol }\end{array}$ & 20 & yes & $\mathrm{NaOH}$ & $\begin{array}{c}\mathrm{pH} \\
\text { adjustments/ } \\
3 \mathrm{~min}\end{array}$ & $65^{\mathrm{g}}$ \\
\hline Iodometric & water & $10-1000 \mu \mathrm{g}$ & $\begin{array}{c}\mathrm{NaIO}_{4} / \\
1.07-10.7 \mathrm{mg}\end{array}$ & 3 & $\begin{array}{l}\text { sodium } \\
\text { molybdate }\end{array}$ & immediately & $\mathrm{no}^{\mathrm{h}}$ & $\mathrm{Na}_{2} \mathrm{~S}_{2} \mathrm{O}_{3}$ & none & $\begin{array}{l}\text { proposed } \\
\text { work }\end{array}$ \\
\hline
\end{tabular}

a Procedures for extracting the analyte or for $\mathrm{pH}$ adjustments, due to the intrinsic characteristics of the extraction solution, were disregarded; ${ }^{\mathrm{b}} 3$ min were considered for titration procedures; 'adapted from the AOCS Ca 14-56 standard; ${ }^{51}$ dbased on the AOCS Ca 14-56 standard; ${ }^{.1}$ ebased on the IRAM 5571 standard; ${ }^{66}$ faccording to the authors; ${ }^{g}$ based on the AOCS Ea 6-51 standard; ${ }^{47}$ husing freshly prepared $\mathrm{NaIO}_{4}$ solution. 
and chloramine-T). ${ }^{58,60}$ There are yet other procedures that require a relatively high quantity of analyte to perform the titration (Table 2). ${ }^{60,61}$

The here proposed method determines smaller amounts of glycerol and uses smaller quantities of periodate than most of the known titrimetric methods (Table 2) for the determination of this analyte, ensuring less consumption of reagents. A procedure is described in the literature which allows the determination of low amounts of glycerol (see Rosas; ${ }^{59}$ Table 2). However, it requires a long time for accomplishment of the Malaprade reaction (30 $\mathrm{min}$ ), and as it is based on the AOCS Ca 14-56 standard it presents the same drawbacks previously reported in this work.

The low values of coefficient of variation, as observed in Table 1, are not common to be obtained in titration of small amounts of analyte. Very diluted solutions are undesirable in titration procedures, since the change-over of $-\log [a]$, where $\mathrm{a}$ is the analyte, as a function of the titrant volume, may not be enough high near the equivalence point in order to produce an evident shift of the indicator color. In this work quite dilute solutions were successfully titrated. One reason of this success is due to the fact that the influence of dilution in redox titrations is less significative than in acidbase, precipitation and complexometric titrations. Besides, the starch/$/{ }_{3}{ }^{-}$indicator acts by a non-redox mechanism, ${ }^{67}$ which makes the color change dependent only on the $\mathrm{I}_{3}{ }^{-}$concentration but not on the reduction potential of the redox reaction.

The quantification of glycerol at low concentrations by the proposed method was possible because an indicator capable of detecting small amounts of $\mathrm{I}_{3}^{-}$was used. The starch indicator provides a limit of detection of $\mathrm{I}_{3}{ }^{-}$of approximately $5 \times 10^{-7} \mathrm{~mol} \mathrm{~L}^{-1} \cdot{ }^{67}$ However, this would not be sufficient if the burette did not have good accuracy
$( \pm 0.01 \mathrm{~mL})$ and , the titrant solution was not diluted enough that small amounts of $\mathrm{I}_{3}^{-}$required large volumes of titrant. These conditions were employed in the proposed method.

The ASTM D1615 standard ${ }^{63}$ reports that the endpoint of an iodometric titration involving the ions iodate and periodate is not stable, fact which can be observed by the return of the blue color in about $5 \mathrm{~min}$, at the end point of the titration. In this case, the titration must continue to be carried out until a stable endpoint is obtained. In the method here proposed, the instability of the endpoint was also observed in some analyses, but the persistence of the absence of the blue color for at least $30 \mathrm{~s}$, after vigorous shaking of the solution, securely indicates the endpoint.

Similarly to the other methods cited here, which employ the Malaprade reaction, the proposed method is adequate for the analysis of samples in absence of glycols with adjacent hydroxyls, since they also do the Malaprade reaction, ${ }^{34,35}$ and also in absence of other impurities which react with periodate to produce iodate.

\section{Biodiesel analysis and recovery tests}

The biodiesels samples here analyzed by the proposed method presented contents above and below the limit allowed by the quality standards $(0.02 \mathrm{~g}$ per $100 \mathrm{~g})$ (Table 3). The recoveries of the added glycerol at three levels of concentrations are in the range from 92.9 to $111 \%$, demonstrating that the proposed procedure presents good accuracy for the determination of free glycerol in the studied matrices.

The extraction of free glycerol was based on the procedure proposed by Luetkmeyer et al. ${ }^{68}$ The authors extracted free glycerol from $400 \mu \mathrm{L}$ of a biodiesel sample

Table 3. Recovery test performed by adding standard solutions of glycerol to biodiesel $(n=5)$

\begin{tabular}{|c|c|c|c|c|}
\hline Biodiesel & $\begin{array}{l}\text { Free glycerol content / } \\
\quad(\mathrm{g} \text { per } 100 \mathrm{~g})\end{array}$ & $\begin{array}{l}\text { Added glycerol / } \\
\text { (g per } 100 \mathrm{~g})\end{array}$ & $\begin{array}{l}\text { Found glycerol / } \\
\text { (g per } 100 \mathrm{~g})\end{array}$ & Recovery / \% \\
\hline & & $0.031 \pm 0.002$ & $0.058 \pm 0.003$ & $100 \pm 5$ \\
\hline \multirow[t]{3}{*}{ Soybean } & $0.0268 \pm 0.0017$ & $0.062 \pm 0.002$ & $0.086 \pm 0.003$ & $97 \pm 3$ \\
\hline & & $0.131 \pm 0.002$ & $0.149 \pm 0.006$ & $93 \pm 5$ \\
\hline & & $0.0306 \pm 0.0003$ & $0.040 \pm 0.002$ & $95 \pm 5$ \\
\hline \multirow[t]{3}{*}{ Palm kernel } & $0.011 \pm 0.003$ & $0.0617 \pm 0.0013$ & $0.071 \pm 0.002$ & $96 \pm 4$ \\
\hline & & $0.1281 \pm 0.0011$ & $0.1304 \pm 0.0010$ & $92.9 \pm 0.4$ \\
\hline & & $0.0305 \pm 0.0004$ & $0.085 \pm 0.014$ & $102 \pm 6$ \\
\hline \multirow[t]{3}{*}{ Macauba kernel } & $0.052 \pm 0.006$ & $0.0631 \pm 0.0010$ & $0.115 \pm 0.002$ & $97 \pm 4$ \\
\hline & & $0.127 \pm 0.003$ & $0.182 \pm 0.003$ & $98 \pm 8$ \\
\hline & & $0.0305 \pm 0.0004$ & $0.049 \pm 0.002$ & $111 \pm 3$ \\
\hline \multirow[t]{2}{*}{ Disposed frying oil } & $0.018 \pm 0.003$ & $0.0631 \pm 0.0010$ & $0.075 \pm 0.009$ & $101 \pm 3$ \\
\hline & & $0.125 \pm 0.004$ & $0.14 \pm 0.03$ & $102 \pm 4$ \\
\hline
\end{tabular}


using $800 \mu \mathrm{L}$ of distilled water, $800 \mu \mathrm{L}$ of absolute ethanol and $1600 \mu \mathrm{L}$ of $n$-heptane. The mixture was shaken in a vortex mixer and the phase separation was assisted by placing this tube in a centrifuge for about two minutes. In the work here reported, the polar phase used was $1600 \mu \mathrm{L}$ of deionized water, the shaking was manual, and the centrifugation was performed for one minute. The good recoveries observed (Table 3) suggest that the adaptation of the procedure is adequate.

The semi-micro-scale extraction of the glycerol contained in the biodiesels samples allowed the optimization of the procedure by reducing the time necessary for the determination of this analyte. Thus, the time required for one single determination is about $10 \mathrm{~min}$ (except the preparation of the standard solutions), a time shorter than that used by other titrimetric methods for the determination of glycerol.

The use of such scale of extraction was only possible because the proposed method allows the determination of the analyte into aqueous solutions in small quantities (10-1000 $\mu \mathrm{g})$.

\section{Conclusions}

As far as we know, the solution of sodium molybdate was used for the first time in the present work, as masking agent for the periodate ion in the titrimetric determination of the glycerol content, involving the Malaprade reaction. This approach provided the development of a method with a set of characteristics superior to any other titrimetric method previously reported for this purpose. It is of simple and fast execution, safe and environmentally secure. It is applicable for the determination of small amounts of glycerol in aqueous solutions. The glycerol content was determined with good accuracy and precision and the obtained results did not differ statistically from those of the reference glycerol solutions.

Periodic blank analysis is recommended to assess whether the periodate in solution suffered important reduction to iodate in an extent that it can affect the titration result. Nevertheless, blank analysis is unnecessary when a freshly prepared periodate solution stored, within a day, in a closed bottle and protected from light. Alternatively, the titrant volume spent for the blank can be discounted from the volume spent in the titration.

The proposed method presented satisfactory results in the analysis of free glycerol content in biodiesels prepared from different raw materials, using a semi-micro scale procedure for the extraction of free glycerol from the matrices.

\section{Acknowledgments}

This study was financed in part by the Coordenação de Aperfeiçoamento de Pessoal de Nível Superior-Brasil (CAPES)-Finance Code 001, and by the Conselho Nacional de Desenvolvimento Cientifico e Tecnológico-Brazil (CNPq).

\section{References}

1. Faccendini, P. L.; Ribone, M. E.; Lagier, C. M.; Sens. Actuators, B 2014, 193, 142.

2. Arévalo, F. J.; Osuna, Y.; Cortez, J. S.; Di, T. A.; Granero, A. M.; Robledo, S. N.; Zon, M. A.; Vettorazzi, N. R.; Martinez, J. L; Segura, E. P; Iliná, A.; Fernandez, H.; Sens. Actuators, B 2017, 244, 949.

3. Semkiv, M. V.; Ruchala, J.; Dmytruk, K. V.; Sibirnya, A.; Trends Biotechnol. 2020, 38, 907.

4. Nanco, C. R.; Poklis, J. L.; Hiler, M. M.; Breland, A. B.; Eissenberg, T.; Wolf, C. E.; J. Anal. Toxicol. 2019, 43, 720.

5. Motia, S.; Bouchikhi, B.; Llobet, E.; El Bari, N.; Talanta 2020 , $216,120953$.

6. Zhao, X.; Procopio, S.; Becker, T.; J. Food Sci. Technol. 2015, 52,7588 .

7. Bortoletto, A. M.; Corrêa, A. C.; Alcarde, A. R.; J. Inst. Brew. 2016, 122, 293.

8. Lachenmeier, D. W. In Advances in Food Authenticity Testing; Lachenmeier, D. W.; Downey, G., eds.; Woodhead Publishing: Cambridge, UK, 2016, ch. 21.

9. Sighinolfi, S.; Baneschi, I.; Manzini, S.; Tassi, L.; Dallai, L.; Marchetti, A.; J. Food Compos. Anal. 2018, 69, 33.

10. Ramonas, E.; Ratautas, D.; Dagys, M.; Meškys, R.; Kulys, J.; Talanta 2019, 200, 333.

11. Martins, C. A.; Fernández, P. S.; Camara, G. A. In Increased Biodiesel Efficiency; Martins, C. A.; Fernández, P. S.; Camara, G. A.; Trindade, M., eds.; Springer: Cham, 2018, p. 159.

12. Yaşar, F.; Fuel 2020, 264, 116817.

13. Chen, W. C.; Li, P. Y.; Chou, C. H.; Chang, J. L.; Zen, J. M.; Electrochim. Acta 2015, 153, 295.

14. ASTM D6584: Standard Test Method for Determination of Total Monoglycerides, Total Diglycerides, Total Triglycerides, and Free and Total Glycerin in B-100 Biodiesel Methyl Esters by Gas Chromatography, West Conshohocken, PA, 2017.

15. Eggly, G. M.; Blackhall, M.; de Araújo, A. G.; Santos, R.; de Araújo, M. C. U.; Pistonesi, M. F.; Microchem. J. 2018, 138, 296.

16. ASTM D6751: Standard Specification for Biodiesel Fuel Blend Stock (B100) for Middle Distillate Fuels, West Conshohocken, PA, 2020.

17. EN 14214: Liquid Petroleum Products - Fatty Acid Methyl Esters (FAME) for Use in Diesel Engines and Heating Applications - 
Requirements and Test Methods, BSI Group: London, United Kingdom, 2013.

18. ANP: Resolução ANP No. 45, de 25 de Agosto de 2014, Publicada no DOU de 26 de Agosto de 2014, 2014, available at https://atosoficiais.com.br/anp/?q=45\%2F2014, accessed in December 2021.

19. Simonzadeh, N.; Ronsen, B.; J. Chromatogr. Sci. 2012, 50, 644.

20. Rainey, C. L.; Shifflett, J. R.; Goodpaster, J. V.; Bezabeh, D. Z.; Contrib. Tob. Res. 2013, 25, 576.

21. AOAC 968.09: Alcohols (Higher) and Ethyl Acetate in Distilled Liquors. Gas Chromatographic Method, Rockville, MD, 1969.

22. AOAC 972.10: Alcohols (Higher) and Ethyl Acetate in Distilled Liquors. Alternative Gas Chromatographic Method, Rockville, MD, 1975.

23. EN 14106: Fat and Oil Derivatives - Fatty Acid Methyl Esters (FAME). Determination of Free Glycerol Content, BSI Group: London, United Kingdom, 2003.

24. EN 14105: Fat and Oil Derivatives - Fatty Acid Methyl Esters (FAME). Determination of Free and Total Glycerol and Mono-, Di-, Triglyceride Contents, BSI Group: London, United Kingdom, 2011.

25. De, A. K.; Chowdhury, P. P.; Chattopadhyay, S. P.; Adv. Phar. 2015, ID 567032.

26. Honório, G. G.; Cunha, J. N.; Assis, K. L. S. C.; Aguiar, P. F.; Andrade, D. F.; Souza, C. G.; D’ Avila, L. A.; Archanjo, B. S.; Achete, C. A.; Pradelle, R. N. C.; Turkovics, F.; Neto, R. S.; D'Elia, E.; J. Solid State Electrochem. 2019, 23, 3057.

27. Assis, K. L. S. C.; Archanjo, B. S.; Achete, C. A.; D'Elia, E.; Mater. Res. 2020, 23, e20190513.

28. Gattas, E. A. L.; Peres, M. F. S.; Br PI 100348-3 2013.

29. Nario, N. A.; Insausti, M.; Domini, C. E.; Crunhut, M.; Energy Fuels 2019, 33, 9925.

30. Goriushkina, T. B.; Shkotova, L. V.; Gayda, G. Z.; Klepach, H. M.; Gonchar, M. V.; Soldatkin, A. P.; Dzyadevych, S. V.; Sens. Actuators, B 2010, 144, 361.

31. Luetkmeyer, T.; Santos, R. M.; Silva, A. B.; Amado, R. S.; Vieira, E. C.; Electroanalysis 2010, 22, 995.

32. Chiles, E.; Wang, Y.; Kalemba, K. M.; Kwon, H.; Wondisford, F. E.; Su, X.; Anal. Biochem. 2019, 575, 40.

33. Narwal, V.; Pundir, C. S.; Int. J. Biol. Macromol. 2019, 127, 57.

34. Malaprade, L.; Comptes Rendus 1928, 186, 382.

35. Zhang, Y.; Zhang, L.; Shao, S.; Chang, X.; Li, M.; ChemistrySelect 2020, 5, 6765 .

36. AOAC 942.22: Cosmetics - Vanishing Cream - Glycerol, Washington, DC, USA, 1990.

37. Bondioli, P.; Bella, L.; Eur. J. Lipid Sci. Technol. 2005, 107, 153.

38. Pisarello, M. L.; Costa, B. O. D.; Veizaga, N. S.; Querini, C. A.; Ind. Eng. Chem. Res. 2010, 49, 8935.

39. Lima, M. B.; Insausti, M.; Domini, C. E.; Pistonesi, M. F.; Araújo, M. C. U.; Band, B. S. F.; Talanta 2012, 89, 21.
40. ASTM D7637: Standard Test Method for Determination of Glycerin Assay by Titration (Sodium Meta Periodate), West Conshohocken, PA, 2015.

41. AOCS Ea 6-94: Determination of Crude Glycerin, Titrimetric Method, Urbana, IL, USA, 2017.

42. Ashworth, M. R. F.; Analytical Methods for Glycerol, $1^{\text {st }}$ ed.; Academic Press: New York, USA, 2017.

43. Pisarello, M. L.; Maquirriain, M. A.; Querini, C. A.; Energy Fuels 2018, 32, 8431.

44. Shishov, A.; Trufanov, I.; Nechaeva, D.; Bulatov, A.; Microchem. J. 2019, 150, 104134.

45. Soares, S.; Rocha, F. R.; Talanta 2020, 209, 120584.

46. Tábua, M. C. M.; Santiago, W. D.; Magalhães, M. L.; Ferreira, V. R. F. F.; Brandão, R. M.; Teixeira, M. L.; Pedroso, M. P.; Machado, M. R.; Nelson, D. L.; Cardoso, M. G.; J. Food Sci. Technol. 2020, 57, 505.

47. AOCS Ea 6-51: Glycerol, Sodium Periodate Oxidation Method, Urbana, IL, USA, 2017.

48. Kang, X. M.; Fan, X. Y.; Hao, P. Y.; Wang, W. M.; Zhao, B.; Inorg. Chem. Front. 2019, 6, 271.

49. Zhou, Y.; Ding, Y.; Gao, W.; Wang, J.; Liu, X.; Xian, M.; Feng, X.; Zhao, G.; Biotechnol. Biofuels 2020, 13, 88.

50. ABNT NBR 15771: Biodiesel - Determinação de Glicerina Livre - Método Volumétrico, Brazil, 2009.

51. AOCS CA 14-56: Total Free and Combined Glycerol Iodimetric - Periodic Acid Method, Urbana, IL, USA, 2017.

52. Belcher, R.; Townshend, A.; Anal. Chim. Acta 1968, 41, 395.

53. Nakashima, Y.; Shen, H.; Kusuyama, K.; Himeno, S.; Anal. Sci. 1999, 15, 725.

54. Ensafi, A. A.; Chamjangali, A. M.; Spectrochim. Acta, Part A 2003, 59, 2897.

55. Rocha Jr., J. G.; dos Santos, M. D. R.; Madeira, F. B.; Rocha, S. F. L. S.; Bauerfeldt, G. F.; da Silva, W. L. G.; Salomão, A. A.; Tubino, M.; J. Braz. Chem. Soc. 2019, 30, 1751.

56. Burgot, J. L.; Ionic Equilibria in Analytical Chemistry, $1^{\text {st }}$ ed.; Springer: New York, USA, 2012.

57. Ghodbane, H.; Hamdaoui, O.; Desalin. Water Treat. 2016, 57, 4100.

58. Dantas, M. B.: Obtenção, Caracterização e Estudo Termoanalítico de Biodiesel de Milho (Zea mays L); MSc Dissertation, Universidade Federal da Paraíba, João Pessoa, Brazil, 2006, avalilable at https://www.ufpb.br/ppgq/ contents/documentos/teses-e-dissertacoes/dissertacoes/2006/ Dissertacao_Manoel_B_Dantas.pdf/view, accessed in December 2021.

59. Rosas, J. C. F.: Produção de Biodiesel Metílico Utilizando Óleo Residual de Fritura via Ultrassom; MSc Dissertation, Universidade Federal do Pará, Belém, Brazil, 2011, available at https://ppgeq.propesp.ufpa.br/ARQUIVOS/dissertacoes/ J\%C3\%BAlio\%20C\%C3\%A9sar\%20Freitas\%20Rosas.pdf, accessed in August 2021. 
60. Hartman, L.; J. Appl. Chem. 1953, 3, 308.

61. Naviglio, D.; Romano, R.; Pizzolongo, F.; Santini, A.; De Vito, A.; Schiavo, L.; Nota, G.; Musso, S. S.; Food Chem. 2007, 102, 399.

62. Bradford, P.; Pohle, W. D.; Gunther, J. K.; Mehlenbacher, V. C.; Oil Soap 1942, 19, 189.

63. ASTM D1615: Standard Test Methods for Glycerol, Ethylene Glycol, and Pentaerythritol in Alkyd Resins (Withdrawn 2004), West Conshohocken, PA, 1995.

64. NP 16018 05: Combustibles. Biodiesel Puro (B100). Requisitos Generales, Paraguay, 2011.

65. Sanchez, D. L. R.: Butanol Production from Glycerol by Clostridium pasteurianum in Defined Culture Media - a Phenotypic Approach; MSc Dissertation, University of
Maryland, College Park, USA, 2009, available at https://drum. lib.umd.edu/bitstream/handle/1903/9665/RamosSanchez_ umd_0117N_10727.pdf?sequence=1\&isAllowed=y, accessed in December 2021.

66. IRAM 5571: Determination of Glycerol Content, Argentina, 2003.

67. Harris, D. C.; Quantitative Chemical Analysis, $8^{\text {th }}$ ed.; W. H. Freeman and Company: New York, USA, 2010.

68. Luetkmeyer, T.; dos Santos, R. M.; da Silva, A. B.; Amado, R. S.; Vieira, E. C.; D’Elia, E.; Electroanalysis 2010, 22, 995.

Submitted: August 5, 2021

Published online: January 6, 2022 